\title{
Diskriminasi Gaya Hidup Hijabers dalam Berita Wolipop
}

\author{
Rr. Pramesthi Ratnaningtyas \\ Program Studi Ilmu Komunikasi, Universitas AMIKOM Yogyakarta \\ Email : pramesthi@amikom.ac.id
}

\begin{abstract}
Abstrak
Penelitian bertujuan melihat penggambaran perempuan berhijab dari berbagai negara yang mendapatkan diskriminasi pada Artikel Hijab Wolipop sepanjang tahun 2019. Ditemukan 18 artikel terkait peristiwa diskriminasi, penolakan, larangan yang dihadapi Muslimah di dunia. Artikel tersebut dianalisis menggunakan pendekatan kualitatif dengan metode analisis wacana Michel Foucault. Dua fokus utama wacana Foucault adalah produksi wacana dan wacana yang terpinggirkan. Hasil penelitian menemukan, Wolipop mengkonstruksikan hijabers masih berada di ranah perjuangan untuk mempertahankan pilihan berbusana, sekaligus mendapatkan hak atau mencapai posisi dan cita-cita yang ingin diwujudkan, meskipun kerap menjadi target kekerasan. Mengenakan hijab merupakan perjuangan hak bagi perempuan muslim di beberapa negara. Bukan hanya berkaitan dengan agama tapi juga cara hidup dan segala hal yang diyakini secara spiritual, walaupun kekuatan untuk melanggengkan steriotipe terhadap hijabers tidak dipersoalkan.
\end{abstract}

Kata Kunci: diskriminasi, hijabers, media online, Wolipop

\begin{abstract}
The study aims to look at the description of women wearing hijab from various countries who have been received discrimination reported in the Wolipop Hijab Articles throughout 2019. 18 articles are found related to incidents of discrimination, rejection, and prohibitions faced by Muslim women in the world. The articles is analyzed using a qualitative approach with Michel Foucault's discourse analysis method. The two main focuses of Foucault's discourse are discourse production and marginalized discourse. The results show that Wolipop constructs a reality that hijabers are still in the realm of struggle to maintain their choice of dress, as well as get their rights or achieve the position and ideals they want, eventhough they are become target of violence. Wearing hijab is a struggle for rights for Muslim women in many countries. It is not only related to religion but also the way of life and everything that is believed spiritually, although the power to perpetuate stereotypes against hijabers is not in question.
\end{abstract}

Keywords: discrimination, hijabers, online media, Wolipop 


\section{PENDAHULUAN}

Program serangkaian berita dan pelaporan yang mendalam paling jelas dikenali karena melibatkan produksi atau pengolahan informasi. Jika ide berita mengejutkan, memiliki kebaruan, menarik dan layak diberitakan, maka akan tampak jauh lebih masuk akal untuk tidak melaporkannya dalam format yang sama setiap hari, tetapi menunggu sesuatu terjadi dan kemudian mempublikasikannya (Luhmann, 1996). Sama halnya gaya hidup yang sudah tak bisa dilepaskan dari masyarakat saat ini. Gaya hidup menjadi salah satu identitas seseorang di lingkungannya. Menurut pemikiran David Chaney (1996), perbedaan pola tindakan antara satu orang dengan orang lain adalah gaya hidup. Suatu tindakan yang dipilih seseorang merupakan gaya hidup yang mendeskripsikan siapa dirinya. Saat manusia mendeskripsikan dirinya, kebutuhan sosial tidak dapat ditanggalkan. Thohir (2020) menyampaikan kebutuhan sosial terbentuk dari upaya untuk melibatkan diri karena berkaitan dengan kebutuhan sandang, pangan dan papan.

Pada saat yang sama, gaya hidup menjadi ladang bisnis yang cukup besar dan menguntungkan. Salah satunya adalah gaya hidup untuk berhijab bagi perempuan Muslim. Beberapa tahun ini, hijab sangat menjadi perhatian karena banyaknya peragaan busana, atau perancang busana yang memunculkan keindahan fesyen hijab. Banyak perempuan Muslim yang memilih berhijrah dengan menutup aurat. Tidak sedikit pula tokoh atau figur publik yang mempopulerkan hijab. Hal ini memunculkan kesan bahwa hijab tidak lagi monoton. Ulya dan MSI (2018) melihat kapitalisme menciptakan fesyen sebagai suatu komoditas. Keadaan tersebut juga tidak bisa dipisahkan dari perkembangan teknologi (Istiani, 2015).

Menurut laporan Thomson Reuters dan Dinar Standard dalam Global Islamic Economy Report, 1,6 miliar konsumen Muslim dunia menghabiskan \$ 266 miliar USD untuk pakaian pada 2013 dan menghabiskan sekitar \$ 484 miliar USD pada 2019. Berdasarkan data tahun 2012, negara-negara Muslim dengan konsumsi pakaian tertinggi adalah Turki sebesar \$ 25 miliar USD. Diikuti Iran dengan \$ 21 miliar USD, Indonesia dengan \$ 17 miliar USD, Mesir dengan \$ 16 miliar USD, dan Arab Saudi sebesar \$ 15 miliar USD. Muslim di Eropa Barat (Jerman, Prancis, Inggris) dan Amerika Utara secara kolektif menghabiskan sekitar \$21 miliar USD untuk pakaian dan alas kaki pada tahun 2012. Secara kolektif, pasar konsumen pakaian Muslim hanya menempati urutan kedua setelah pasar terbesar di dunia. Amerika Serikat sendiri dengan pengeluaran \$ 494 miliar USD (Guide, 2016). Selain itu, CBI (Exporting Islamic Wear to Europe, 2019) atau the Centre for the Promotion of Imports from Developing

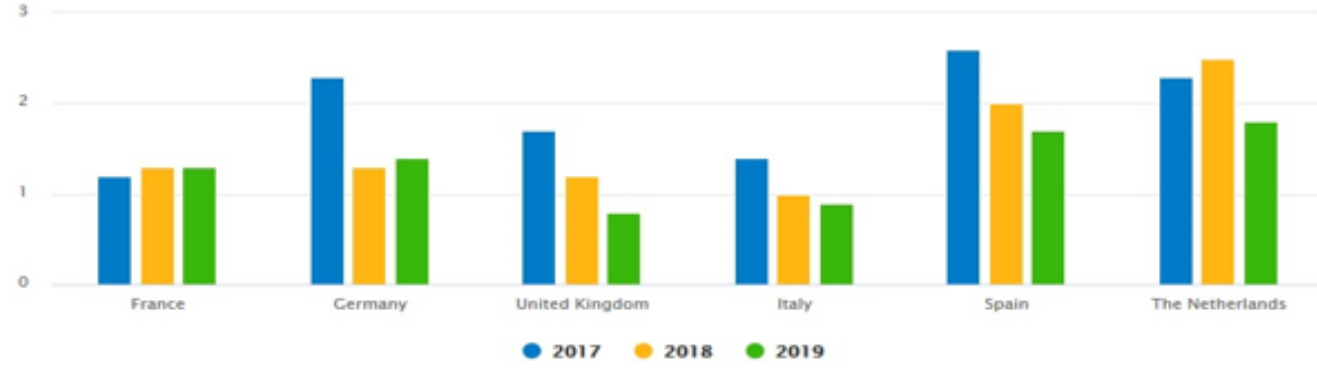

Gambar 1. Pertumbuhan konsumsi atau pengeluaran pribadi, termasuk pasar pakaian Islam di Eropa, dari Exporting Islamic Wear to Europe, 2019 
Countries mengungkapkan pemasaran pakaian Islami tidak lagi terbatas pada merek yang menargetkan Muslim kaya untuk suatu perayaan seperti Ramadan. Pasar bergerak menuju arus utama, dari merek mewah ke toko di pinggir jalan.

Di dalam perubahan dinamika masyarakat tersebut, juga terdapat kebaruan informasi dan pengetahuan yang menarik untuk ditayangkan atau dimuat dalam suatu media massa. Semua itu tidak lepas dari kemampuan media dalam membingkai fenomena yang ada. Mengingat realitas pertama merupakan kenyataan atau fakta, dan Luhmann (1996) menyatakan bahwa media tidak mampu menampung semua yang ada dalam realitas pertama. Ada 'manipulasi' karena media mempunyai struktur, organisasi, dan reproduksi sendiri. Untuk itu, realitas media juga berkaitan dengan referensi dimana batas antara referensi-diri dan referensi-lain adalah perbedaan.

Realitas media atau realitas kedua diciptakan agar masyarakat mendapatkan informasi tentang suatu peristiwa yang sedang atau telah berlangsung di dunia. Media dalam masyarakat urban atau kapitalis telah memainkan peran yang sangat penting dalam mengkonstruksi, mengkreasi, memproduksi dan mengkomodifikasi gaya hidup perempuan berhijab. Hegemoni gaya hidup menjadi struktur kuasa dinamik yang berusaha memastikan otoritasnya dalam kehidupan. Strinati (2016) melihat hegemoni sebagai konsekuensi dari konflik kelas, yang menyetujui satu sisi perjuangan, kelompok dominan, dengan mengorbankan pihak lain. Hijab sendiri dalam perjalanannya menjadi salah satu identitas, sekaligus alat yang digunakan untuk menempatkan individu dalam kelas sosial.

Jika merunut dari teori feminis, cenderung melihat bagaimana individu bersikap yang akhirnya sangat berpengaruh dalam bagaimana mereka berkomunikasi. Sedangkan Butler (dalam Littlejohn \& Foss, 2009) mengatakan, teori komunikasi harus menjelaskan cara individu bernegosiasi, menolak, dan melampaui identitas mereka dalam masyarakat yang sangat gender. Artinya, bagaimana individu bernegosiasi untuk menerima atau menolak suatu gaya hidup tertentu dalam sistem masyarakat. Berbagai pilihan gaya hidup yang bertaburan di masyarakat, fesyen memiliki posisi tersendiri. Termasuk di dalamnya pilihan untuk berhijab. Troxell dan Stone melalui Fashion Merchandising (dalam Lestarysca \& Febriana, 2013) mengatakan, Fesyen dimaknai sebagai gaya dalam kurun waktu tertentu yang mendapat tempat dalam kehidupan anggota masyarakat secara kebanyakan. Bisa dikatakan, fesyen merupakan gaya yang diminati, dirasa sesuai dengan kepribadian seseorang, dan dalam kurun waktu tertentu.

Salah satu media yang menyuguhkan warta ataupun bacaan terkait gaya hidup perempuan adalah portal berita Wolipop. Media online tersebut dirilis 9 Desember 2009. Satu dari beberapa portal di bawah naungan detikcom, Wolipop berada di peringkat ke-5 versi situs peringkat internasional Alexa (Topsites, 2019). Erfancorner (2012) mengungkapkan, detikcom telah menjadi bagian dari Trans Corp pada 3 Agustus 2011. Tak hanya itu, detikcom juga menjadi pemberitaan online terbesar di Indonesia. Pageview detikcom mencapai 50 juta lebih per hari. 
Wolipop sendiri seringkali menjadi acuan bacaan terkait citra perempuan dan fesyen, baik dari dalam atau pun luar negeri (Lestarysca \& Febriana, 2013). Website ini juga memiliki beberapa rubrik menarik dan mampu memikat perhatian pembaca. Rubrik tersebut yaitu Fashion, Hijab, Beauty, Relationship, Living, Work \& Money, Horoscope, Indeks. Rangkaian berita, cerita, dan wawasan terkait gaya hidup perempuan disajikan secara apik dalam rubrikrubrik tersebut dengan gaya bahasanya yang ringan, serta tata letak yang menarik dan fullcolour, sehingga rubrik yang ditampilkan Wolipop mampu mendorong dan membangkitkan motivasi pembaca perempuan untuk hadir dan mengeksplorasi informasi yang diberikan. Rubrik Hijab di Wolipop memiki sub rubrik Hijab Style, Hijab Update, Tutorial, dan Hijab Profile. Dalam Hijab Update terdapat sub rubrik lagi bernama Artikel Hijab yang memberitakan tentang sosok-sosok perempuan yang menekuni suatu bidang, prestasi dan permasalahannya. Artikel Hijab di Wolipop tidak hanya memberitakan tentang sosok dari Indonesia saja, tapi juga perempuan Muslim dari berbagai negara dengan permasalahannya karena memutuskan untuk berhijab. Sosok perempuan berhijab dari berbagai negara yang diberitakan Wolipop masih mendapat penolakan atau diskriminasi tersendiri karena pilihan berbusananya yang menutup aurat.

Berbagai belahan dunia masih sarat akan diskriminasi, khususnya terhadap perempuan. Organisasi Buruh Internasional ILO (BBC News Indonesia, 2016) memaparkan laporan berdasarkan data dari 178 negara yang menunjukkan tingkat keikutsertaan dan keterlibatan perempuan 25,5\% lebih rendah dibandingkan kaum adam pada tahun 2015 di bidang pekerjaan. Kualitas pekerjaan yang didapatkan perempuan masih dianggap sepele dan remeh di beberapa negara. Perempuan masih terus mendapatkan tantangan agar bisa mendapatkan jalan masuk terhadap pekerjaan yang layak. Badan Hak Asasi Fundamental Uni Eropa (Tempo.co, 2017) melakukan survei terhadap 10.500 umat Muslim di 15 negera termasuk Inggris, Prancis, Jerman, Belanda, Swedia dan Spanyol pada akhir tahun 2015 dan awal 2016. Penelitian tersebut menemukan bahwa sekitar $40 \%$ perempuan berhijab atau mengenakan niqab mendapat diskriminasi saat melamar pekerjaan. Sebesar $9 \%$ mendapatkan pelecehan, dan sekitar 40\% Muslim Eropa diperlakukan tidak adil dalam mengakses layanan publik seperti kesehatan dan pendidikan. Selain itu juga saat mencari pekerjaan dan rumah.

Dalam laporan Forgotten Women: The Impact of Islamophobia on Muslim Women in the UK yang dilakukan atas permintaan European Network Against Racism dan British Group Faith Matter, ditemukan diskriminasi gender dan agama atas kaum Muslimah di Inggris. Perlakuan buruk terjadi di ruang publik, tempat kerja, dan media daring. Dilaporkan pula terjadi pelecehan, tekanan seksual, diskriminasi di hampir semua sisi kehidupannya. Sebanyak 43\% Muslimah di Inggris diperlakukan berbeda saat wawancara kerja. Angka tersebut naik terhadap perempuan yang mengenakan jilbab/hijab. Setidaknya sebanyak 50\% mengalami diskriminasi agama dan alasan memakai jilbab menjadi faktor pokok (Saju, 2016). Dengan demikian, dari permasalahan tersebut, penelitian ini bertujuan untuk mengetahui bagaimana penggambaran perempuan berhijab dari berbagai negara yang mendapatkan diskriminasi pada Artikel Hijab Wolipop selama kurun waktu 2019.

\section{METODOLOGI PENELITIAN}


Penelitian ini menggunakan pendekatan kualitatif dengan metode analisis wacana. Eriyanto (2011) menjelaskan bahwa analisis wacana adalah penerapan penggunaan bahasa, khususnya politik bahasa. Posisi bahasa yang sentral tidak lepas dari penggambaran suatu subjek dan ideologi yang terkandung di dalamnya. Bahasa yang dianalisis menghubungkan suatu konteks yang dipakai untuk tujuan dan praktik tertentu. Salah satu tokoh analisis wacana adalah Michel Foucault yang mengenalkan wacana sebagai praktik sosial. Wacana memiliki fungsi untuk mengontrol, menormalkan, dan mendisiplinkan individu. Selain itu, ada kuasa yang dipraktikan dalam suatu ruang lingkup, dimana banyak posisi strategis berkaitan satu sama lain.

Kekuasaan tidak diberikan, dipertukarkan, atau dipulihkan, melainkan dilaksanakan, dan itu hanya ada dalam tindakan. Kekuasaan berakar begitu dalam dan efeknya sulit untuk dihindari adalah fakta. Kekuasaan telah ada dan selalu ada. Tak ada seorang pun yang berada di luar kekuasaan. Selain itu, tidak ada celah bagi pihak lain untuk mematahkan dan memasuki sistem. Namun, hal ini tidak berarti, seseorang harus menerima bentuk dominasi yang tidak bisa dihindari tersebut, atau menerima hak istimewa absolut di hadapan hukum. Walaupun seseorang tidak bisa menjadi "kekuatan luar", bukan berarti seseorang akan terjebak dan diposisikan kalah apapun yang terjadi (Foucault \& Gordon, 1980).

Eriyanto (2011) menyodorkan dua fokus utama agar bisa memahami wacana Foucault, yakni produksi wacana dan wacana yang terpinggirkan. Dalam produksi wacana, realitas dipahami sebagai seperangkat konstruk yang dibentuk melalui wacana. Selain itu, perlu juga untuk memahami adanya struktur diskursif dalam wacana. Struktur diskursif ini membuat objek atau peristiwa terlihat nyata, dan tidak dilihat sebagai sistem yang abstrak dan tertutup. Struktur tersebut membatasi pandangan mana yang benar dan mana yang salah. Ciri wacana terdapat pada batasan bidang dari objek, definisi dari perspektif yang paling dipercaya dan dipandang benar. Persepsi tentang objek, dibatasi pandangan yang mendefinisikan bahwa sesuatu yang ini benar dan yang itu adalah salah. Dengan kata lain, wacana merupakan sebuah wilayah dimana khalayak berpikir dengan jalan tertentu, bukan dengan yang lain. Dalam kehidupan bermasyarakat, ada berbagai wacana yang berbeda. Kekuasaan memilih dan mendukung wacana tertentu, hingga akhirnya menjadi dominan. Di saat yang sama, wacana yang lain terpinggirkan atau terpendam. Wacana dominan memiliki dua konsekuensi. Pertama, memberi arahan bagaimana suatu objek dibaca dan dipahami. Pandangan dibatasi dalam batas struktur diskursif. Kedua, struktur diskursif yang tercipta atas suatu objek tidak berarti kebenaran. Batas-batas yang muncul akan membatasi pandangan dan menyebabkan wacana yang tidak dominan menjadi terpinggirkan. Suatu wacana yang terpinggirkan berakibat pada khalayak yang tidak mendapatkan informasi dari beragam sudut pandang suatu peristiwa. Wacana yang terpinggirkan berkaitan dengan praktik ideologi.

Penelitian ini sendiri menganalisis pemberitaan di rubrik Artikel Hijab Wolipop selama sepanjang tahun 2019. Dari berbagai artikel di sub rubrik Artikel Hijab, ditemukan 41 berita. Sebanyak 18 artikel menjadi unit analisis, diantaranya terkait peristiwa diskriminasi, penolakan, atau larangan yang dihadapi Muslimah di dunia. Keputusan perempuan untuk berhijab membuatnya kesulitan untuk mengakses fasilitas publik. Akses mereka tidak hanya 
dibatasi, tapi juga dilarang. Perempuan berhijab juga kesulitan untuk mengikuti kegiatan olahraga, dilematis dengan pekerjaan yang diinginkan. Selain itu juga mendapatkan kekerasan secara verbal dan non verbal. Perempuan berhijab yang mendapatkan perlakuan diskriminasi, berada di posisi yang termarjinalkan.

Berita-berita tersebut kemudian dianalisis menggunakan analisis wacana Michel Foucault. Analisis diawali dengan mengkaji berita-berita yang termasuk dalam produksi wacana. Dimana produksi wacana berkaitan dengan struktur diskursif yang melingkupinya. Dilanjutkan dengan melihat dari wacana yang terpinggirkan yang berimplikasi pada tidak dihadirkannya kesempatan bagi khalayak untuk mendapatkan informasi dari beragam sudut pandang, serta berujung pada praktik ideologi (Eriyanto, 2011). Adapun gambaran bagan penelitian adalah sebagai berikut;

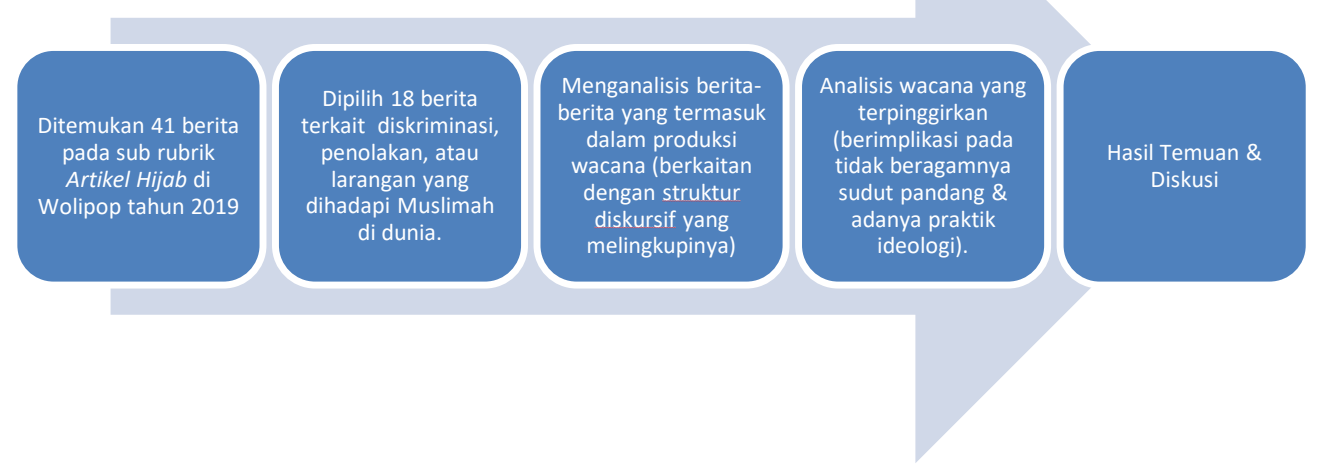

Gambar 2. Bagan Penelitian, dari olahan peneliti, 2020

\section{HASIL DAN PEMBAHASAN}

\section{Tidak Ada Hak yang Sama bagi Perempuan Muslim}

Sebanyak 18 artikel pemberitaan di Wolipop terkait peristiwa diskriminasi, penolakan, atau larangan yang dihadapi Muslimah di dunia, terdapat 10 artikel yang mengisahkan tentang perempuan berhijab yang berada di ranah diskriminasi. Sepuluh artikel tersebut berjudul sebagai berikut, "2 Wanita Muslim Nekat Langgar Larangan Pakai Burkini di Kolam Renang Prancis”, "Disebut Batman hingga Penculik Anak, Ini yang Dilakukan Para Wanita Bercadar", "Kisah Selebgram Bercadar, Dulu Dilempar Batu Kini Sukses Jadi Fotografer", "Kontroversi Hijabers Diminta Lepas Jilbab Saat Ikut Wajib Militer", "Mulai Hari Ini, Belanda Resmi Larang Warganya Pakai Burqa dan Cadar", "Pakai Cadar dari SMA, Remaja Ini Dapat Pandangan Sinis dan Dijauhi”, "Prancis Larang Wanita Berhijab Antar Anak 'Field Trip' Sekolah", "Saat Hijab Turban Jadi Kontroversi di Malaysia, Pemakainya Dianggap Pendosa", "Selebgram AS Curhat Keluarganya Alami Diskriminasi Saat Salat di Tempat Umum", "Viral Hijabers Curhat Ditolak Masuk Klub Malam, Diminta Lepas Jilbab”.

Diskriminasi yang merundung perempuan Muslim atau hijabers bisa terjadi dalam berbagai bentuk. Hasanah (2016) memberikan tiga bentuk diskriminasi yakni langsung, tidak 
langsung dan sistematik. Ketika seseorang diperlakukan berbeda karena perilaku atau sikap, maka termasuk dalam diskriminasi langsung. Sebaliknya, diskriminasi tidak langsung hadir dalam kebijakan. Berbeda dengan diskriminasi sistematik dengan bentuk kesewenangwenangan sebagai hasil dari akar sejarah, norma, struktur atau adat yang dibuat masyarakat setempat, dan diturunkan pada generasi berikutnya. Stasio, Lancee, Veit, dan Yemane (2019) melihat diskriminasi anti-Muslim dan diskriminasi berbasis asal (etnis) secara mandiri berkontribusi pada kerugian besar yang dihadapi etnis minoritas dan agama.

Pemberitaan yang dihadirkan Wolipop ini menunjukkan bagaimana perempuan berhijab masih dianggap tidak memiliki hak yang sama dengan masyarakat lainnya. Mereka dipandang dengan stigma atau stereotipe negatif karena "berbeda". Gender perempuan saja sudah mendapat diskriminasi, ditambah dengan keputusan untuk menggunakan hijab sebagai identitas. Ketidaksamaan hak memunculkan pidana yang mengharuskan perempuan berhijab untuk membayar denda jika melanggar kebijakan hukum. Sebagaimana dalam berita berjudul “2 Wanita Muslim Nekat Langgar Larangan Pakai Burkini di Kolam Renang Prancis”. Artikel tersebut menggambarkan situasi saat Hassiba dan Latifa melanggar aturan dengan tetap berenang menggunakan burkini. Beberapa orang disekitarnya mendukung dan memberikan tepuk tangan atas keberanian dua Muslimah tersebut. Hanya saja, setelah berenang selama satu jam, mereka harus diinterogasi polisi dan membayar denda sebesar $€ 35$ atau sekitar Rp560 ribu.

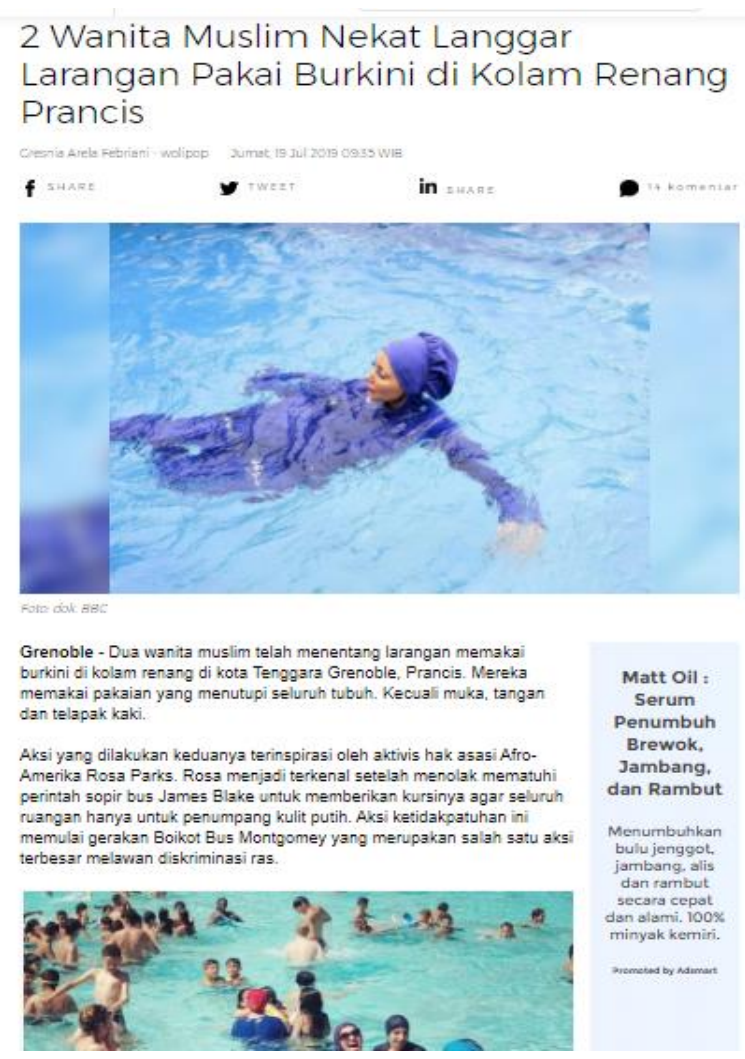

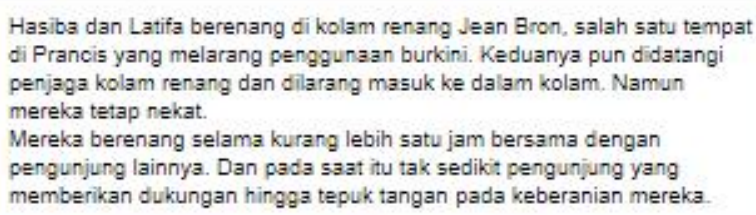

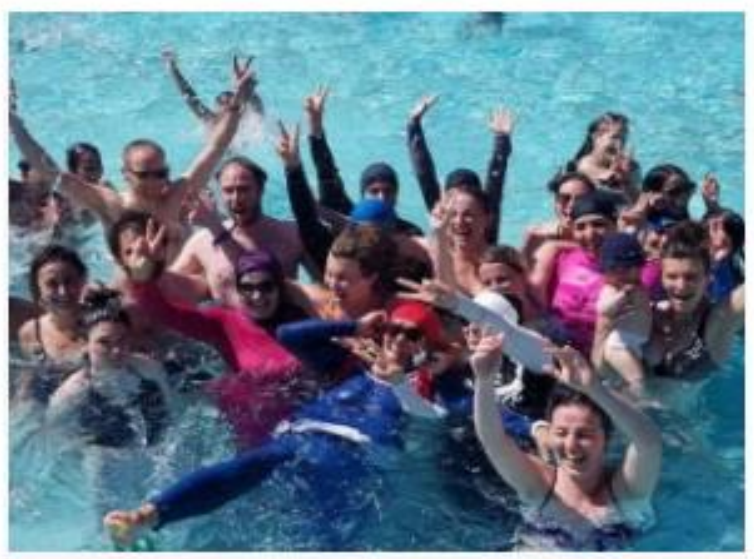

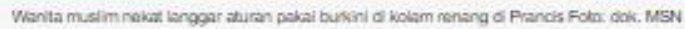

Setelah berenang, Hasiba dan Latifa harus menjalani interogasi polisi. Mereka kemudian didenda sebesar $€ 35$ atau sektar Rp 560 ribu karena telah melanggar aturan hukum, demikian menurut laporan media France Bleu.

Gambar 3. Potongan contoh artikel yang dimuat Wolipop, dari Febriani, 2 Wanita Muslim Nekat Langgar Larangan Pakai Burkini di Kolam Renang Prancis, 2019 
Dukungan sementara dan akibat yang harus diterima terlihat tidak sesuai, karena pada akhirnya ada sejumlah nominal yang harus dikeluarkan. Selain itu, khalayak di sekitar kolam renang yang awalnya mendukung, tidak memberikan bantuan apapun kepada Hassiba dan Latifa saat diinterograsi. Keadaan ini bisa kembali terulang di lain kesempatan. Perempuan Muslim yang berhijab lainnya juga akan mendapatkan perlakuan yang sama jika melanggar larangan tersebut. Mengingat adanya kebijakan diskriminatif dan prasangka di Prancis, yang membuat mereka tidak mendapat perlakuan yang sama untuk menikmati atau menggunakan layanan publik dan infrastruktur kota. Diskriminasi tidak langsung yang hadir melalui kebijakan ini, menempatkan Hassiba dan Latifa pada posisi tidak diuntungkan.

Serupa dengan kondisi di tanah air, seperti artikel yang memberitakan tentang fotografer bercadar Azthry Ibrahim yang mendapatkan perlakuan tidak menyenangkan secara verbal karena menggunakan cadar. Azthry mendapat sebutan setan dan maling. Adapula ibuibu yang menakut-nakuti anaknya yang kalau menangis akan diculik oleh Azthry. Selain itu, ia juga pernah dilempar batu oleh anak kecil ketika sedang berjalan. Perlakuan yang sama juga menimpa pendiri komunitas wanita bercadar Niqab Squad, Indadari. Ia diteriaki setan oleh anak kecil. Belum lagi jika boncengan naik motor, disebut "batman". Tasya, salah satu siswa SMA di Bekasi, juga sempat merasakan perlakuan sinis dari lingkungan sekitarnya. Beberapa orang juga secara halus menghindarinya.

Penggunaan cadar sendiri masih menjadi perdebatan. Sudirman (2019) menyampaikan bahwa cadar atau niqab adalah satu satu pakaian yang dikenakan perempuan di masa Jahiliyyah sampai masa Islam. Nabi Muhammad SAW tidak mempersoalkan niqab, tapi juga tidak mewajibkan, menghimbau atau menyunahkan penggunaan niqab. Berbeda dengan Sartika dan Yusuf (2020) yang berpendapat cadar merupakan identitas dalam gaya hidup syar'i. Kondisi ini membuat pengguna niqab bisa bertahan dalam lingkungan berbeda dan sistem sosial. Hal tersebut berkaitan dengan kekuasaan atau otoritas baru yang diproduksi bagi yang mengenakan cadar. Wajar jika penggunaan cadar membawa konsekuensi penolakan yang lebih besar daripada jilbab (Ratri, 2011). Belum lagi ada stigma berbeda terhadap perempuan bercadar (Fitrillah, Halik, dan Musi, 2020).

Diskriminasi muslimah di dalam negeri berkaitan dengan stigma eksklusivitas dan radikalisme. Pandangan tersebut juga berlangsung di negara lain. Beberapa negara juga melarang penggunaan cadar. Prancis menjadi wilayah pertama di Eropa yang melarang penggunaan cadar pada tahun 2011. Yulikhah (2016) mengungkapkan bahwa Prancis melarang penggunaan simbol agama di sekolah. Prancis menilai simbol agama tersebut adalah jilbab. Ismoyo (2017) juga melihat bahwa integritas perempuan di Prancis terhadap haknya untuk mengenakan penutup kepala sebagai salah satu kewajiban dalam agamanya dibatasi oleh pemenuhan kewajiban sipil.

Tidak hanya itu, pada bulan Mei 2019, Prancis mengesahkan aturan yang melarang perempuan berhijab mendampingi anak di kegiatan school trip atau field trip. Begitu pula dengan Austria yang tidak mengijinkan penggunaan simbol keagamaan di sekolah, yang dalam hal ini mengarah pada muslimah atau hijabers. Disusul kebijakan dari pemerintah Denmark dan Jerman yang melarang penggunaan cadar. Belanda melakukan langkah serupa 
dengan melarang penggunaan cadar dan burqa di tempat umum dan instansi publik, seperti rumah sakit, sekolah, transportasi umum bus dan kereta, serta kantor pemerintah. Kebijakan ini berlaku sejak 1 Agustus 2019.

Asumsi terhadap perempuan muslim juga ditunjukkan hampir sebagian besar warga Amerika. Mereka menganggap perempuan muslim tidak berpendidikan dan lemah. Kondisi tersebut dikaitkan dengan Islam sebagai agama yang banyak menerapkan burka dan patriarki. Hal itu dilihat sebagai alat pemaksaan dan membuat Islam dinilai keras serta negatif (Nizmi, 2015). Diskriminasi karena ketidakpahaman khalayak terhadap cara beribadah umat Islam juga terjadi pada hijabers Noor Tagouri dan keluarga yang didatangi petugas keamanan saat sedang salat di sebuah Convention Center di Amerika Serikat. Berbeda dengan Soaliha Iqbal yang mendapatkan intimidasi. Ia diminta melepaskan jilbabnya oleh penjaga pintu klub malam di Sydney. Polisi yang berada di sekitar pun juga memintanya untuk meninggalkan lokasi.

Dari permasalahan dalam pemberitaan tersebut, ada struktur diskursif yang sengaja dibangun bahwa perempuan berhijab dan menggunakan cadar berkaitan dengan stigma seram, momok yang menakutkan, radikal, serta teroris. Terlihat dari pemberitaan berjudul "Disebut Batman hingga Penculik Anak, Ini yang Dilakukan Para Wanita Bercadar" dengan penggalan kalimat sebagai berikut ;

"Penggunaan cadar di Tanah Air masih menjadi polemik, ada yang pro dan kontra. Penggunaan cadar yang sering disalahgunakan untuk kegiatan yang negatif seperti aksi terorisme membawa dampak pada imej cadar.

Dalam kehidupan sehari-hari, para wanita bercadar kerap harus menghadapi stigma negatif dari masyarakat. Seperti yang dialami fotografer bercadar Azthry Ibrahim. Dia pernah dilempar batu oleh anak kecil hingga dituding sebagai penculik anak." (Febriani, Disebut Batman hingga Penculik Anak, Ini yang Dilakukan Para Wanita Bercadar, 2019).

Keadaan yang dihadapi perempuan Muslim memperlihatkan bahwa mereka harus "ditaklukkan" melalui larangan dan aturan sedemikian rupa agar sistem kekuasaan yang berlaku tidak tergoyahkan. Perempuan Muslim sebagai kaum marjinal diperlakukan tidak sama, karena cara berpakaiannya yang tidak umum bagi beberapa kalangan. Hingga kemudian sejumlah organisasi hak asasi dan hak sipil pun memilih menghindar dari realita diskriminasi terhadap perempuan Muslim atau perempuan berhijab. Diskriminasi yang hadir karena adanya dominasi yang sifatnya manipulatif ini akhirnya berujung pada ketidakadilan dan mengarah pada kekerasan. Diskriminasi dilegitimasi dengan menekan perempuan berhijab secara budaya, dan dianggap tidak memiliki hak. Serupa dengan pemikiran Sari (2018) yang menjelaskan bahwa cara pandang (seperti agama), keluarga, dan komunitas (negara) merupakan tiga indikator awal perkembangan dan perubahan budaya. Ketiga hal tersebut saling berkaitan dalam memberikan keyakinan yang paling penting dari suatu budaya. Berbeda dengan Haryatmoko (2013) melihat diskriminasi dibawa oleh situasi atau sistem yang bisa dibongkar atau dirawat. Diskriminasi yang juga berkaitan dengan adanya ketakutan terhadap Islam radikal (Wahidah \& Nuranisah, 2020). 
Realita yang dimunculkan Wolipop melalui berita atau artikel juga berkaitan dengan semakin maraknya Islamophobia di berbagai negara. Hatem Bazian dan Maxwell Leung (2014) mengatakan bahwa meningkatnya sentimen negatif terhadap masyarakat Muslim berkaitan dengan hadirnya industri Islamophobic yang terorganisasir dan didanai dengan baik. Hadirnya industri Islamophobic mampu menangkap wacana masyarakat dan publik tanpa pembantahan serius. Keadaan tersebut juga berkaitan tentang bagaimana suatu kekuatan dan kekuasaan dalam benak masyarakat yang membalikkan masa depan perempuan Muslim. Sebagaimana Bazian \& Leung menjelaskan bahwa ;

We maintain that the success of the Islamophobic industry is centered on problematizing Islam in civil society discourse to such an extent that it has made it possible for civil and human rights organizations to distance themselves from the affected communities (Bazian \& Leung, 2014).

Kesuksesan industri Islamophobic dihadirkan dalam berbagai tindakan, pengalaman, informasi dan pengetahuan tentang Muslim dan Islam. Berbagai konstruksi peristiwa yang berkaitan dengan Muslimah berhijab dan Islam seperti eksklusivitas, radikalisme, teroris, dan ISIS dihadirkan, diberitakan, diteruskan dalam masyarakat. Pada akhirnya, membawa pandangan dan pemikiran tertentu kepada masyarakat setempat terhadap Muslimah berhijab. Kesadaran, pikiran dan kehendak individu pada akhirnya diwujudkan dalam beragam tindakan aktif yang diterima perempuan berhijab di dunia. Di dalamnya terdapat pengawasan dan pengontrolan untuk patuh terhadap suatu mekanisme yang diciptakan. Kehidupan perempuan Muslim dikendalikan oleh pandangan atau stigma yang dimunculkan dan dikembangkan. Industri Islamophobic membawa dan menghadirkan kekuasaan yang tidak terlihat dan tidak disadari. Tentunya, bertujuan untuk menimbulkan keteraturan dalam suatu versi tertentu yang ingin diwujudkan masing-masing negara, atau pemilik kekuasaan.

Pada pemberitaan lainnya, Wolipop juga menyoroti diskriminasi yang dialami Muslimah di ranah dunia kerja atau bidang yang ditekuni, khususnya yang berkaitan atau bersinggungan dengan sisi maskulin. Terdapat delapan artikel terkait hal tersebut. Artikel berjudul "Ini Anggota Kongres Berhijab yang Diserang Trump dengan Komentar Rasis" menceritakan tentang Ilhan Omar. Ia adalah anggota kongres Amerika Serikat yang memakai hijab dan diserang komentar rasis oleh Donald Trump. Ilhan bersama ketiga anggota kongres AS lain dianggap berasal dari negara dengan pemerintahan kacau dan seharusnya kembali ke Somalia. Komentar rasis memperlihatkan adanya keberhasilan industri Islamofobia dengan media. Selain itu, juga berkaitan dengan bentuk diskriminasi lainnya seperti penolakan pekerjan serta urusan politik dan kebijakan negara. Pendapat Donald Trump merupakan contoh komentar yang berangkat dari popularitas sentimen yang berkaitan dengan Islamofobia (Bukar, 2020).

Berbeda dengan artikel berjudul "Inspiratif, Kisah Atlet Angkat Besi Berhijab Pertama yang Bergelar Doktor" yang mengisahkan tentang hijabers berdarah Pakistan-Amerika bernama Kulsoom Abdullah. Ia menekuni olahraga angkat besi, dan perjuangannya di bidang tersebut sempat terhalang saat mengikuti kejuaraan angkat besi nasional pada tahun 2010. Ia ditolak karena mengenakan hijab. Pengalaman diskriminasi juga sudah menjadi hal biasa 
baginya. Hasan (2019) berpendapat bahwa partisipasi perempuan dalam olahraga sudah mendapatkan legitimasi agama. Persepsi memarginalkan perempuan terjadi karena adanya bias makna atas teks-teks keagamaan terkait kapasitas perempuan di ruang publik. Pemahaman terhadap teks-teks keagamaan para pemikir muslim modern yang cenderung liberal dianggap tidak sesuai kaidah tafsir yang berlaku. Pada sisi lain, ulama klasik memberikan interpretasi yang cenderung patriarkal dan mengedepankan konsep maskulinitasnya.

Kisah seniman dan illustrator dari Stockholm Swedia bernama Munira Yussuf merasa tidak memiliki sosok yang bisa menghargainya sebagai perempuan Muslim keturunan Afrika Timur. Ia pernah berkali-kali ditolak sekolah seni, dan merasa sendiri karena tidak banyak yang membicarakan seni dengannya, ataupun menyoroti keberadaannya. Kisahnya dihadirkan dalam artikel berjudul "Jadi Minoritas, Hijaberss Keturunan Afrika Mendobrak Lewat Karya Seni”. Hampir serupa dengan peselancar berhijab pertama di Iran, Shahla Yasini. Pengalaman hidup Shahla dihadirkan melalui berita judul "Kenalan dengan Shahla Yasini, Peselancar Berhijab Pertama Asal Iran”. Diberitakan ia mengalami hambatan dari aturan berpakaian dan pemikiran dari masyarakat Iran yang masih sangat konservatif. Itu yang menyebabkan ia dipandang sebelah mata. Dalam bidang lainnya, dihadirkan dalam "Kisah Inspiratif Hijaberss Kulit Hitam yang Berkali-kali Ditolak Klub Bola". Berita tersebut menceritakan remaja kulit hitam dari Somalia bernama Iqra Ismail yang pernah empat kali ditolak masuk klub bola. Salah satu penolakan karena Iqra tidak bisa menggunakan celana dan baju lengan pendek. Ia pun kerap kali mendapatkan pertanyaan karena menggunakan hijab dan berpuasa.

Sosok Amber Von Grat dalam artikel "Pemadam Kebakaran Berhijab Cantik Curi Perhatian di Kanada", harus memikirkan dan mengupayakan bahan hijab yang sesuai dengan pekerjaannya. Amber merupakan personel pemadam kebakaran di Parkland Country Fire Department. Ia harus terus mencari cara agar tetap bisa berhijab dan mencari pakaian yang menutup auratnya. Hal itu dikarenakan tidak semua bahan hijab dapat dikenakan dan dikhawatirkan meleleh terkena panas api. Di saat yang sama, ia juga harus berurusan dengan kostum pemadam kebakaran yang terbilang berat. Hijabers lainnya, Sannah Husain dalam judul "Kisah Inspiratif Petinju Berhijab Penyandang Disabilitas yang Tangguh" berusaha menunjukkan kemampuannya agar tidak dipandang berbeda dan negatif oleh masyarakat. Hijabers asal Pakistan yang lahir dan dibesarkan di Glasgow Skotlandia ini adalah atlet tinju. Sannah juga menderita myasthenia gravis yang menyebabkan kelemahan otot dan albinisme yang berdampak pada kulit memutih dan masalah penglihatan. Pengalaman diskriminasi lainnya dialami Noor Alexandria Abukaram dalam artikel berjudul "Remaja SMA Ini Didiskualifikasi dari Lomba Lari karena Pakai Hijab”. Noor yang tinggal di Sylvania, Ohio ini dicabut haknya untuk bertanding pada perlombaan lari lintas negara tingkat SMA. Diskualifikasi tersebut dikarenakan ia tidak diberikan izin untuk berlomba dengan mengenakan hijabnya.

Pengalaman hidup yang dialami secara nyata oleh masing-masing narasumber tersebut merupakan realitas pertama. Berbeda dengan isi berita Wolipop yang merupakan realitas media atau kedua yang menunjukkan bahwa kekuasaan ada dimana-mana, dan kekuasaan ada 
di dalam kekuasaan itu sendiri, seperti organisasi olahraga, kejuaraan olahraga, instansi, perusahaan dan sebagainya. Dari kondisi ini, terlihat bahwa artikel Wolipop membawa suatu wacana bagaimana kekuasaan berlaku secara sistematis dan memproduksi kebenarannya. Perempuan Muslim atau hijabers diatur, dikontrol dan didisiplinkan melalui wacana yang terus diproduksi dan disalurkan dalam hubungan sosial. Memproduksi kategorisasi suatu tindakan tertentu yang dipandang baik atau buruk. Mengintimidasi perempuan Muslim karena adanya wacana lain yang ada di luar kekuasaan tersebut. Perempuan beragama Islam dengan pilihannya untuk menutup aurat, seolah menjadi kambing hitam. Kehadirannya terlihat hanya sebagai komoditas yang dijadikan bahan untuk melegitimasi suatu kekuasaan.

Fakih (2013) menjelaskan stereotipe yang merupakan konstruksi sosial mengakibatkan Muslimah mendapatkan penindasan kultural dan ideologi. Akibatnya, perempuan Muslim harus bekerja lebih keras, dan mendapat ketidaknyamanan secara emosional. Pengetahuan yang dianggap sebagai bidang yang netral rupanya juga mengandung kekuasaan. Proses hegemoni hadir melalui berbagai unsur negara, seperti lembaga pendidikan, kemasyarakatan, media massa dan sebagainya untuk melanggengkan cara pandang yang sudah dibangun. Ratnaningtyas (2020) melihat bahwa berita yang dihadirkan berkaitan dengan minat dan pola konsumsi yang berkaitan dengan peristiwa atau kejadian yang nyata di kehidupan khalayak masyarakat. Publik yang tertarik untuk mengetahui harus patuh melihat atau membaca rangkaian berita dari susunan program media. Hingga pada akhirnya, melupakan kesadaran kritis terhadap suatu realitas bahwa tidak semua perempuan berhijab adalah eksklusif, radikal, anggota teroris, memiliki tujuan negatif, dan tidak layak untuk "hadir" dalam suatu bidang tertentu yang ditekuni.

\section{Sudut Pandang Pilihan}

Terpinggirkannya wacana pada suatu pemberitaan, membawa beberapa dampak yakni, tidak dihadirkannya kesempatan bagi khalayak untuk mendapatkan informasi dari beragam sudut pandang, serta berujung pada praktik ideologi (Eriyanto, 2011). Wolipop melalui Artikel Hijab mencoba memberikan gambaran diskriminasi yang tidak hanya berkaitan dengan gender dan ras, tetapi juga yang bersifat keagamaan. Khususnya, yang dihadirkan dalam bentuk busana sebagai salah satu identitas keagaamaan. Menurut Haryatmoko (2013) diskriminasi dengan membawa agama berkaitan dengan ideologi. Di saat yang sama, wacana agama lekat dengan kekuasaan, kebenaran serta pengetahuan. Kekuasaan menjalankan sistem pilihan untuk tidak memberikan dukungan pada suatu pandangan atau pemikiran yang minoritas dan dirasa meresahkan, yakni masyarakat muslim, yang dalam artikel Wolipop adalah hijabers. 


\begin{abstract}
Jakarta - Prancis menjadi salah satu negara di Eropa yang memiliki aturan ketat untuk muslim. Negara ini menjadi yang pertama melarang pemakaian cadar untuk wanita muslim di tempat umum.

Pada Mei 2019, Prancis meresmikan aturan baru. Pemerintah Prancis melarang wanita berhijab menemani anak di kegiatan school trip atau field trip.

Pada peraturan tersebut, pemerintah Prancis melarang pemakaian atribut keagamaan secara umum. Tapi, dilansir dari Dailymail, Prancis menargetkan wanita muslim yang memakai hijab.
\end{abstract}

Gambar 4. Potongan berita berjudul "Prancis Larang Wanita Berhijab Antar Anak 'Field Trip' Sekolah", dari Putri, 2019

Matzani, Dashper, \& Fletcher (2017) mengingatkan bahwa mengenakan jilbab merupakan tanda adanya suatu perbedaan secara visual dan ada rasa tidak nyaman dengan citra jilbab yang ada di Barat. Semua itu juga berkaitan dengan identitas agama yang membawa konflik karena adanya perbedaan. Elaborasi nilai dari suatu identitas agama dan tingkat kepentingan identitas dalam suatu peristiwa merupakan hasil dari negosiasi politik yang diberi konteks. Identitas bisa dipertanyakan, ditafsirkan kembali, serta dimanfaatkan dalam proses sosial dan negosiasi politik (Thufail \& Ramstedt, 2011).

Pemberitaan di Artikel Hijab Wolipop memiliki arahan tentang bagaimana suatu permasalahan terkait Muslim yang berhijab untuk dibaca dan dipahami. Artikel Hijab Wolipop menghadirkan sudut pandang pilihan dan siap pakai. Secara tidak langsung, pembaca diajak untuk memahami bahwa pilihan menjadi hijabers atau menggunakan cadar adalah suatu hal yang memiliki konsekuensi tersendiri di masyarakat, baik di tanah air, khususnya di beberapa negara lainnya yang non-Islam. Steriotipe tentang perempuan berhijab dan bercadar masih berkaitan dengan radikalisme dan tindakan teroris yang terjadi di belahan dunia. Dauda (2020) menjelaskan, pandangan negatif terhadap muslim disebabkan kebencian anti-muslim, intoleransi agama, rasisme, xenofobia yang merupakan berkembangnya gerakan ektrimis. Muslim juga menjadi sasaran serangan verbal dan fisik, baik langsung ataupun tidak langsung.

Walaupun begitu, ada bagian dalam artikel Wolipop yang memunculkan dan memberikan langkah-langkah panjang dari perjuangan hijabers, khususnya yang menggunakan cadar atau burqa agar bisa diterima dalam lingkungannya. Pada saat yang sama, diskriminasi dan hukuman bagi hijabers atau masyarakat Muslim yang melanggar peraturan masih ditegakkan secara tegas di negara-negara Amerika Serikat dan Eropa. Tidak sedikit dari hijabers yang berjuang dengan langkah masing-masing untuk tetap "bertahan" dalam lingkungan yang memiliki pandangan dominan dan prasangka terhadap agama Islam dan diri mereka. Hilangnya hak yang sama dalam mengakses suatu fasilitas, layanan atau infrastruktur milik publik masih terjadi. Perempuan muslim juga dihadapkan pada suatu keadaan yang menempatkan mereka untuk dapat mencari jalan keluar sendiri atau melalui kelompokkelompok tertentu. Dengan kata lain, jika mengutip Amani Hamdan (2007), maka penggunaan hijab menjadi suatu bentuk perlawanan terhadap pemaksaan budaya Barat. 
Hukum awalnya dibuat untuk menimbulkan keteraturan. Hasanah (2016) berpikir bahwa khalayak luas mempercayai hukum dihadirkan untuk membawa keadilan. Nyatanya, hukum justru menempatkan kelompok yang lemah dalam ketidakberdayaan. Hal itu juga tidak lepas dari budaya patriarki yang memandang perempuan sebagai sosok yang rentan (Mulia, 2018). Khususnya perempuan muslim yang merupakan kategori yang paling rentan. Mereka dikesampingkan dalam sarana pendidikan, pekerjaan, kesehatan, sanitasi dan diabaikan dari hak-hak dasar mereka (Dimitrov \& Nongkynrih, 2017). Begitu pula dengan realitas kedua yang dimunculkan Wolipop melalui artikel berjudul "2 Wanita Muslim Nekat Langgar Larangan Pakai Burkini di Kolam Renang Prancis", "Mulai Hari Ini, Belanda Resmi Larang Warganya Pakai Burqa dan Cadar", "Prancis Larang Wanita Berhijab Antar Anak 'Field Trip' Sekolah", "Saat Hijab Turban Jadi Kontroversi di Malaysia, Pemakainya Dianggap Pendosa". Artikel tersebut menunjukkan bahwa hukum yang berlaku baik yang baru ditetapkan atau yang konvensional, menempatkan perempuan berhijab pada posisi minor. Mereka tidak memiliki kuasa dihadapan masyarakat dan lingkungannya. Pilihan mereka menutup aurat dengan cara berbusana masing-masing menimbulkan kontroversi yang berakibat pada hadirnya ketakutan, dilanggarnya hak atas diri mereka sendiri dan hak untuk mengakses fasilitas publik.

Dalam bidang olahraga, banyak perempuan Muslim dilarang atau dianggap tidak mampu berpartisipasi. Lingkungan mereka juga membutuhkan pertimbangan tertentu terkait aturan berpakaian. Pakaian olahraga dapat menimbulkan masalah ketika aturan berpakaian melarang perempuan Muslim mengenakan pakaian olahraga gaya Barat (Buongiorno, 2016). Diskriminasi atau sikap negatif dari penyedia layanan atau instansi dan organisasi olahraga berkaitan dengan kurangnya kesadaran dan kemungkinan salah menafsirkan agama. Bagi banyak perempuan Muslim, keyakinan dan nilai-nilai agama memberi makna pada cara-cara menyusun dan mendekati kehidupan mereka. Islam adalah aspek fundamental dari identitas mereka. Pendekatan perempuan Muslim atau hijabers terhadap olahraga seringkali ditentukan oleh faktor agama, budaya dan etnis (Muslim Women in Sport, 2010). Hal tersebut yang muncul ada artikel Wolipop berjudul "Kenalan dengan Shahla Yasini, Peselancar Berhijab Pertama Asal Iran", "Remaja SMA Ini Didiskualifikasi dari Lomba Lari karena Pakai Hijab”, "2 Wanita Muslim Nekat Langgar Larangan Pakai Burkini di Kolam Renang Prancis", "Inspiratif, Kisah Atlet Angkat Besi Berhijab Pertama yang Bergelar Doktor", dan "Kisah Inspiratif Hijaberss Kulit Hitam yang Berkali-kali Ditolak Klub Bola”. Kelima artikel tersebut menghadirkan sosok Shahla Yasini (peselancar berhijab pertama asal Iran), Noor Alexandria Abukaram (atlet lari dari sekolah menengah di Northview Sylvania Ohio), Hassiba dan Latifa (mengenakan burkini di kolam renang di kota Tenggara Grenoble Prancis), Kulsoom Abdullah (atlet angkat besi), serta Iqra Ismail (gadis Muslim dari Somalia). Mereka sempat kesulitan mendapatkan kesempatan yang sama karena cara berpakaian. Padahal para hijabers ini berjuang untuk melakukan yang terbaik saat mengenakan jilbab. Matzani, Dashper, \& Fletcher (2017) melihat bahwa mengenakan jilbab dalam olahraga di negara non-Islam seperti Inggris juga membuka kemungkinan kesalahan pengenalan budaya yang mungkin tidak sesuai dengan pemahaman mayoritas masyarakat terkait pakaian olahraga yang cocok. Di sisi lain, Buongiorno (2016) juga mengungkapkan bahwa meskipun hak asasi manusia dilindungi pada 
tingkat tertinggi, tapi kemungkinan ada intrusi oleh organisasi internasional yang melarang atlet perempuan untuk bersaing dalam kompetisi olahraga internasional.

Permasalahan yang dihadirkan dalam Artikel Hijab Wolipop juga memberikan sudut pandang yang seadanya dan menyebabkan hadirnya wacana yang tidak ditonjolkan. Wacana yang berkaitan dengan kekuasaan, praktik ideologi, kebenaran yang dibentuk karena dimapankan. Eriyanto (2011) menyampaikan batas yang muncul akan membatasi pandangan dan menyebabkan wacana yang tidak dominan menjadi terpinggirkan. Hal tersebut berakibat hilangnya informasi dari beragam sudut pandang suatu peristiwa. Pandangan yang berkaitan hadirnya dominasi yang tidak terhindarkan. Walaupun begitu, seseorang tidak berarti harus menerima bentuk dominasi tersebut atau menerima hak istimewa absolut di hadapan hukum (Foucault \& Gordon, 1980).

Pada saat kekuasaan membentuk kebenaran dan "rezimnya" sendiri, maka pengetahuan dari suatu pandangan kekuasaan memproduksi ekonomi politik kebenaran terhadap hijabers. Keadaan yang kemudian dimapankan, diwujudkan dan dilestarikan. Selain relasi kuasa antara pemerintah dan warga negara, dalam pemberitaan yang dimunculkan juga terdapat relasi kuasa antara pria dan perempuan, serta stigma dan identitas. Artikel di Wolipop juga mengindikasikan adanya kemungkinan persaingan antar kekuasaan, kemampuan, kecerdasan dan pemahaman atas suatu bidang tertentu yang ditekuni Muslimah. Wajar jika pada akhirnya Ali, Yamada, dan Mahmood (2015) memandang bahwa perempuan Muslim menjadi target diskriminasi berdasarkan pakaian atau cara berbusananya. Perempuan berhijab diasosiasikan berada di kelas sosial yang rendah. Padahal kelas sosial rendah berkaitan dengan kepuasan kerja yang rendah pula. Moffic, Peteet, Hankir, dan Awaad (2019) menjelaskan bahwa perilaku Islamophobia, khususnya terhadap perempuan Muslim yang berhijab atau bercadar, bermula dari persepsi yang salah dan ketidakpahaman serta perasaan takut masyarakat barat terhadap Islam yang juga diperkuat dengan diskriminasi gender dan ras. Sayangnya, fakta bahwa perempuan di berbagai belahan dunia, terlepas dari agama dan budayanya, cenderung menjadi objek pelecehan (Rajagukguk \& Yesicha, 2019). Hal tersebut dianggap lumrah. Kejahatan dan kebencian terhadap perempuan Muslim karena prasangka dan persepsi ini berujung pada pembatasan gerak sosial dan pengekangan kesempatan untuk berperan di bidang sosial, pekerjaan, dan politik yang kemudian secara efektif menghambat asimilasi perempuan Muslim di semua level.

Tidak hanya itu, intimidasi dengan sumpah serapah dan penghinaan rasial adalah hal yang biasa terjadi di jalanan. Perempuan Muslim dilabeli dengan citra yang sangat stereotipe. Berbeda dengan mereka yang kuat dan mandiri, digambarkan sebagai anomali. Kesulitan besar yang dihadapi perempuan Muslim saat tinggal di lingkungan yang bermusuhan menempatkan mereka pada kerentanan yang lebih besar untuk mengembangkan posttraumatic stress disorder, merusak kepercayaan diri mereka, dan menghambat kemampuan mereka untuk berasimilasi di masyarakat. Kejahatan kebencian dan retorika negatif yang konstan terhadap perempuan Muslim tidak hanya mempengaruhi kualitas hidup dan membatasi akses mereka, tetapi juga memengaruhi fungsi keluarga dan kemampuan membesarkan anak. Masalah kesehatan mental ibu secara langsung memengaruhi perilaku 
anak-anak, kinerja akademis, kapasitas untuk berasimilasi, dan kesejahteraan (Moffic, Peteet, Hankir, \& Awaad, 2019). Dapat dikatakan bahwa hijabers yang diberitakan Wolipop masih berada di ranah perjuangan meski bukan di zaman perang. Mereka berjuang untuk mempertahankan pilihan berbusana, sekaligus mendapatkan hak atau mencapai posisi dan cita-cita yang ingin diwujudkan. Langkah sederhana hingga kemampuan untuk tidak menyerah pada keadaan menjadi cara mereka untuk mempertahankan pilihan yang diambil. Stereotipe yang berkembang di masyarakat tidak menyurutkan mereka untuk terus bertahan dari resiko tinggi yang merusak kepercayaan diri hingga kemampuan untuk berasimilasi di lingkungan tertentu. Pembatasan gerak sosial dan pengekangan kesempatan untuk berperan di bidang sosial, pekerjaan, dan politik bukan takdir yang bisa mereka pilih. Pandangan negatif sebagai salah satu akibat dari tindakan terorisme atau radikal yang mengatasnamakan Islam dan tidak mereka lakukan pun, mau tidak mau harus dihadapi. Hal tersebut hanya menjadi bagian dari proses pendewasaan diri mereka dalam berbagai pandangan negatif. Bertahan sekaligus menunjukkan prestasi di lingkungan yang "menabrakkan" realitas yang tidak dipahami suatu kelompok masyarakat terhadap agama Islam dan pilihan seseorang untuk menutup aurat. Tidak bersikap frontal terhadap hukum dan peraturan, terkadang menjadi pilihan yang mau tidak mau mereka lakukan untuk bisa menunjukkan bahwa hijabers tidak berkaitan dengan teroris. Walaupun ada beberapa artikel yang menunjukkan sikap perempuan Muslim yang memang melanggar aturan, karena mereka merasa haknya dilanggar. Hingga akhirnya, muslimah tersebut mendapatkan perlakuan yang tidak menyenangkan. Kondisi bagaimana hijabers menyelesaikan permasalahan yang menimpa dirinya, memberikan penggambaran bahwa perempuan Muslim belum kehilangan "cahayanya". Meskipun di saat yang sama, kekuatan yang memiliki kekuasaan dan melanggengkan steriotipe terhadap hijabers tidak dipersoalkan.

\section{PENUTUP}

Artikel Hijab Wolipop memberikan penggambaran tentang diskriminasi yang diterima perempuan berhijab di beberapa negara di dunia. Mereka dianggap tidak memiliki hak yang sama, dan memiliki stereotipe yang berkembang di masyarakat. Hal tersebut tidak menyurutkan Muslimah bertahan dari resiko tinggi yang merusak kepercayaan diri untuk berasimilasi. Pembatasan gerak sosial dan pengekangan kesempatan bukan takdir, melainkan bagian dari proses pendewasaan diri hijabers dalam bertahan sekaligus menunjukkan prestasi di lingkungan yang tidak menguntungkan. Wolipop mengkonstruksikan Hijabers masih berada di ranah perjuangan untuk mempertahankan pilihan berbusana, sekaligus mendapatkan hak atau mencapai posisi dan cita-cita yang ingin diwujudkan meskipun kerap menjadi target kekerasan. Mengenakan hijab merupakan perjuangan hak bagi perempuan muslim di beberapa negara. Bukan hanya berkaitan dengan agama tapi juga cara hidup dan segala hal yang diyakini secara spiritual.

Sistem kekuasaan negara dan berbagai institusi publik dikokohkan dengan menaklukkan perempuan muslim melalui larangan dan aturan dengan menempatkan mereka dalam posisi yang serba terbatas. Kekuasaan yang hadir membentuk kebenaran dan "rezimnya" sendiri. Pengetahuan dari suatu pandangan kekuasaan memproduksi ekonomi 
politik kebenaran terhadap hijabers kemudian dimapankan, diwujudkan dan dilestarikan. Artikel di Wolipop juga mengindikasikan adanya kemungkinan persaingan antar kekuasaan, kemampuan, kecerdasan dan pemahaman atas suatu bidang tertentu yang ditekuni. Kondisi bagaimana hijabers merespon situasi dan menyelesaikan permasalahan yang menimpa dirinya, memberikan penggambaran bahwa mereka tidak kehilangan semangat meskipun disaat yang sama, kekuatan penguasa melanggengkan steriotipe terhadap hijabers tidak dipersoalkan.

Penelitian ini juga bisa menjadi masukan bagi berbagai pihak yang bersinggungan dengan hijabers. Pilihan mereka untuk menutup aurat bukan semata-mata sekedar gaya, melainkan ideologi dan identitas yang dibangun dengan kepercayaan. Kenyataan yang diterima dari lingkungan sekitar tidak selalu sesuai dengan ekspektasi. Namun, mereka mampu bertahan melalui prestasi, pemikiran kuat dan sikap yang tidak bisa mudah untuk dirubah. Dari hal ini, maka penelitian selanjutnya bisa dilakukan dengan menggunakan metode lain seperti survei atau analisis isi untuk melihat perubahan dari hadirnya diskriminasi terhadap perempuan muslim dalam kurun waktu tertentu di berbagai media massa lainnya.

\section{DAFTAR PUSTAKA}

Ali, S. R., Yamada, T., \& Mahmood, A. (2015). Relationships of The Practice of Hijab, Workplace Discrimination, Social Class, Job Stress, and Job Satisfaction Among Muslim American Women. Journal of Employment Counseling, December 2015, Volume 52, 146-157.

Bazian, H., \& Leung, M. (2014). Editorial Statement. Islamophobia Studies Journal, 7-9.

Bukar, A. A. (2020). The Political Economy of Hate Industry: Islamophobia in the Western Public Sphere. Islamophobia Studies Journal, Fall 2020, Vol. 5, No. 2, 152-174.

Buongiorno, J. (2016). Sex Discrimination in Sport: A Challenge Also for States with High Standards of Human Rights Protection? Diperoleh dari (https://papers.ssrn.com/sol3/ papers.cfm?abstract_id=3061118)

Chaney, D. (1996). Lifestyles Sebuah Pengantar Komprehensif. Yogyakarta: Jalasutra.

Dauda, K. O. (2020). Islamphobia and Religious Intolerance: Threats to Global Peace and Harmonious Co-Existence. Qudus International Journal of Islamic Studies (QIJIS) Volume 8, Number 2, 257-292.

Dimitrov, G., \& Nongkynrih, N. (2017). A Study on Muslim Women Political Participation in India. International Journal of Research Volume 04 Issue 09, 41-54.

Erfancorner. (2012, Desember 18). Sejarah Detikcom sebagai Pelopor Portal Berita Indonesia. Sejarah Detikcom sebagai Pelopor Portal Berita Indonesia. Jakarta, DKI Jakarta, Indonesia: EC Publishing Media.

Eriyanto. (2011). Analisis Wacana, Pengantar Analisis Teks Media. Yogyakarta: LKiS.

Exporting Islamic Wear to Europe. (2019). Diperoleh dari (https://www.cbi.eu: https://www.cbi.eu/market-information/apparel/islamic-wear) 
Fakih, M. (2013). Analisis Gender dan Transformasi Sosial. Yogyakarta: Pustaka Pelajar.

Febriani, G. A. (2019, Juli 19). 2 Wanita Muslim Nekat Langgar Larangan Pakai Burkini di Kolam Renang Prancis. Detik. Diperoleh dari https://wolipop.detik.com/hijabupdate/d-4630755/2-wanita-muslim-nekat-langgar-larangan-pakai-burkini-di-kolamrenang-prancis

Febriani, G. A. (2019, November 10). Disebut Batman hingga Penculik Anak, Ini yang Dilakukan Para Wanita Bercadar. Detik. Diperoleh dari https://wolipop.detik.com/hijab-update/d-4779199/disebut-batman-hingga-penculikanak-ini-yang-dilakukan-para-wanita-bercadar

Fitrillah, C., Halik, A., \& Musi, S. (2020). Self Disclosure Muslimah Bercadar di Desa Lumaring Kabupaten Luwu. Jurnal Washiyah Volume 1 No 1, 119-135.

Foucault, M., \& Gordon, C. (1980). Power/Knowledge: Selected Interviews and Other Wriings 1972-1977. New York: Pantheon Books.

Guide, G. B. (2016). Manufacturing | Indonesia Aiming to be the Islamic Fashion Capital by 2020. Diperoleh dari (http://www.gbgindonesia.com: http://www.gbgindonesia.com /en/manufacturing/article/2016/indonesia_aiming_to_be_the_islamic_fashion_capital _by_2020_11646.php)

Hamdan, A. (2007). The Issue of Hijab in France: Reflections and Analysis. Muslim World Journal of Human Rights Vol. 4, Iss. 2 [2007], Art. 4: 1-27. doi: 10.2202/15544419.1079 .

Haryatmoko. (2013). Dominasi Penuh Muslihat: Akar Kekerasan dan Diskriminasi. Jakarta: Gramedia Pustaka Utama.

Hasan, R. (2019). Partisipasi Perempuan dalam Olahraga Perspektif Hermeneutika Hadis Fazlur Rahman. Jurnal Studi Ilmu-ilmu al-Qur'an dan Hadis Vol. 20, No. 1, 43-61.

Hasanah, D. U. (2016). Kekerasan dan Diskriminasi terhadap Perempuan dalam Pandangan Hukum. Jurnal Harkat: Media Komunikasi Islam Tentang Gender dan Anak, 12 (2), 109-116.

BBC News Indonesia. (2016, Maret 8). ILO: Pekerja Perempuan Masih Alami Diskriminasi. $B B C$. Diperoleh dari www.bbc.com: https://www.bbc.com/indonesia /dunia/2016/03/160308_dunia_pekerja_perempuan

Ismoyo, P. J. (2017). Islamofobia di Prancis : Diskriminasi Perempuan sMuslim Maghribi. Jurnal Penelitian Sosial Cakrawala, 217-244.

Istiani, A. N. (2015). Konstruksi Makna Hijab Fashion Bagi Moslem Fashion Blogger. Jurnal Kajian Komunikasi, Volume 3, No. 1, 48-55.

Lestarysca, \& Febriana, P. (2013). Konstruksi Citra Perempuan dalam Media Online. Kanal : Jurnal Ilmu Komunikasi, Volume 2, 50-64. doi : https://doi.org/10.21070/kanal.v2i1.275.

Littlejohn, S. W., \& Foss, K. A. (2009). Encyclopedia of Communication Theory. California: SAGE Publications Inc.

Luhmann, N. (1996). The Reality of The Mass Media. Stanford California: University Press. 
Matzani, R., Dashper, K., \& Fletcher, T. (2017). Gender Justice? Muslim Women's Experiences of Sport and Physical Activity in the UK. Dalam J. Long, T. Fletcher, \& B. Watson, Sport, Leisure and Social Justice (h. 70-83). London: Routledge.

Moffic, H. S., Peteet, J., Hankir, A. Z., \& Awaad, R. (2019). Islamophobia and Psychiatry : Recognition, Prevention, and Treatment. Switzerland: Springer Nature Switzerland AG.

Mulia, M. (2018). Perempuan dalam Gerakan Terorisme di Indonesia. Al-wardah: Jurnal Kajian Perempuan, Gender dan Agama Volume: 12 Nomor: 1, 80-95.

Muslim Women in Sport. (2010). Diperoleh dari (https://www.womeninsport.org/wpcontent/uploads/2017/10/Muslim-Women-in-Sport.pdf?x99836)

Nizmi, Y. E. (2015). Pandangan Amerika Terhadap Perempuan Muslim Pasca Serangan Sebelas September 2001. Jurnal Kajian Politik Dan Masalah Pembangunan, 16231632.

Rajagukguk, P. H., \& Yesicha, C. (2019). Komodifikasi Wacana Sensitif Gender Firza Husein Di Mediaindonesia.Com. Jurnal Riset Komunikasi, 2(1), 74-88. https://doi.org/10.24329/jurkom.v2i1.59

Putri, S. (2019, Mei 22). Prancis Larang Wanita Berhijab Antar Anak 'Field Trip' Sekolah. Detik. Diperoleh dari https://wolipop.detik.com/hijab-update/d-4559698/prancislarang-wanita-berhijab-antar-anak-field-trip-sekolah.

Ratnaningtiyas, R. P. (2020). Sampah Dalam Kacamata Media Online. Jurnal Komunikasi Vol. 12, No. 1, 16-29.

Ratri, L. (2011). Cadar, Media, dan Identitas Perempuan Muslim. Jurnal Forum Vol. 39, no. 2, 29-37.

Saju, P. S. (2016, Mei 26). Muslimah Inggris Hadapi Diskriminasi Jender dan Agama. Kompas. Diperoleh dari https://internasional.kompas.com/read/2016/05/26/09141621/muslimah.inggris.hadapi .diskriminasi.jender.dan.agama?page $=$ all

Sari, W. P. (2018). Analisis Wacana Kritis Kasus Penyerangan Terhadap Jemaah Ahmadiyah di Cikeusik. Jurnal Komunikasi Vol. 10, No. 1, 87-94.

Sartika, V., \& Yusuf, M. (2020). "Bercadar Itu Pengakuan”; Reproduksi Makna Cadar di Kalangan Pengguna. Indonesian Journal of Religion and Society, Vol. 02 (02), 87-96.

Stasio, V. D., Lancee, B., Veit, S., \& Yemane, R. (2019). Muslim by Default or Religious Discrimination? Results from a Cross-National Field Experiment on Hiring Discrimination. Journal of Ethnic and Migration Studies, 1-22.

Strinati, D. (2016). Popular Culture. Yogyakarta: Narasi Pustaka Promethea.

Sudirman, M. (2019). Cadar Bagi Wanita Muslimah (Suatu Kajian Perspektif Sejarah). Diktum: Jurnal Syariah dan Hukum Volume 17 Nomor 1, 49-64.

Tempo.co. (2017, September 22). Survei Diskriminasi Terhadap Muslim di Eropa Meningkat. Tempo. Diperoleh dari https://dunia.tempo.co/read/911491/survei-diskriminasiterhadap-muslim-di-eropa-meningkat/full\&view=ok 
Thohir, M. (2020). Realitas Kehidupan dalam Perspektif Antropologis. Jurnal Ilmu Bahasa dan Sastra (Nusa) Vol. 15 No. 1, 76-83.

Thufail, F. I., \& Ramstedt, M. (2011). Kegalauan Identitas. Jakarta: Gramedia Widiasarana Indonesia.

Topsites. (2019, Desember 28). Alexa. Diperoleh dari https://www.alexa.com/topsites/countries/ID

Ulya, I., \& MSI. (2018). Muslimah Cosmopolitan Lifestyle: Antara Syari'at, Trend Masa Kini dan Kapitalisasi Agama. Palita: Journal of Social - Religion Research Vol. 3, No. 2, 97-120.

Wahidah, N., \& Nuranisah, E. (2020). Diskriminasi Perempuan Bercadar Dalam Perspektif Hegemoni. Al-Mada; Jurnal Agama, Sosial dan Budaya Vol. 3, No. 1, 39-49.

Yulikhah, S. (2016). Jilbab Antara Nilai Kesalehan dan Fenomena Sosial. Jurnal Ilmu Dakwah Vol. 36, No.1, 96-117. 